
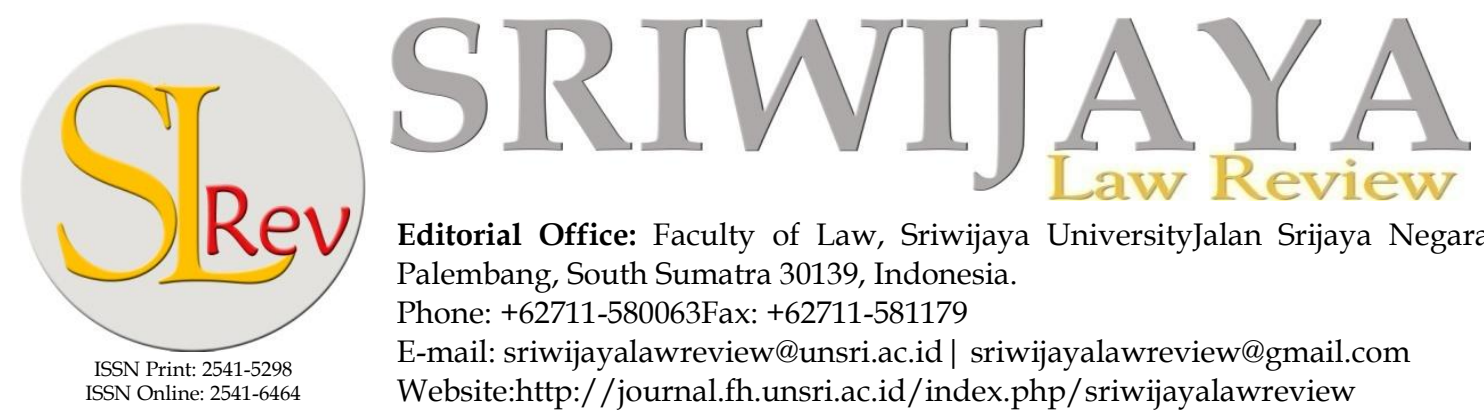

Editorial Office: Faculty of Law, Sriwijaya UniversityJalan Srijaya Negara, Palembang, South Sumatra 30139, Indonesia. Phone: +62711-580063Fax: +62711-581179

E-mail: sriwijayalawreview@unsri.ac.id| sriwijayalawreview@gmail.com Website:http://journal.fh.unsri.ac.id/index.php/sriwijayalawreview

\title{
LEGAL PROTECTION AGAINST WOMEN VICTIMS BY THE INDONESIAN DOMESTIC VIOLENCE ACT 23, 2004
}

\author{
Hanafi Arief ${ }^{1}$
}

\begin{abstract}
Domestic Violence, particularly against women is a social phenomenon which tends to increase from year to year and even from day to day.Many countries enacted special legislation to protect women from domestic violence based on the United Nation Declaration on the Elimination of Violence Against Women (CEDAW). Indonesia adopted the conventions based on the Indonesian Act No. 7 of 1984 on the Convention on the Elimination of All Forms of Discrimination against Women, and issued Presidential Decree No. 9 of 1998 concerning the Commission on Violence against Women.Indonesia then enacted special legislation on domestic violence in 2004, namely Domestic Violence Act 23, 2004.This paper aims to understand how the Domestic Violence Act 23, 2004 protects women victims of domestic violence. The sources of law study arethe basic rules and regulations, international conventions which have binding force legally. This is a library research using normative judicial approach, and the analysis is descriptive qualitative. The legal protection of women victims of domestic violence is an obligation, especially for countries that uphold human rights, because of the domestic violence constitutes crimes against humanity that are outstanding. This crime happens at any time either known or not, so it is described as an iceberg phenomenon. In addition, because this matter is private, many people do not want to intervene the matter. The strong culture of not interfering ones'affairs also influencesthe police in law enforcement. Police often gives less respect for the report of the victims, and even ask the victims to go back to her husband or family.
\end{abstract}

Keywords: legal protection; women victims; and domestic violence.

\section{ARTICLE HISTORY:}

Received:

Dec 19, 2016; Reviewed: Dec 26, 2016

Accepted:

Jan 4, 2016; Published: Jan 30, 2017.

\footnotetext{
${ }^{1}$ Faculty of Law, University of Kalimantan Muhammad Arsyad Al-Banjari Banjarmasin E-mail:hanafi_arief@yahoo.com
}

\section{INTRODUCTION}

An overview of the different families is different from contemporary families in the past. Many families today enjoy the results of technological progress, industry and others. As a result, the replacement of human power with mechanical power affects one's behavior in the family. This may causereducement of a family function, causing the family ties become brittle and 
eventually grow individualistic attitudes. The other hand, the family in the past is the family that has not been affected by the various advances, so that became a strong family bond in the cause of the family member required the role of each party making their life bessed and calm.

Individualistic attitude in lifestyle, with the emphasis on self-interest without any regard to the interests of other family members, may cause one be able to take advantage and pleasure in the suffering of others. Relationships between individuals may cause changes in the real meaning or essence of the "individual" that is, as social beings. In this condition when the basic needs are not found, then she will lead individual to serious frustration that may impact the behavior, andeasily violates the existing norms in society, both social and religious norms, as well as the norms of the legislation.

Violence against women is a crucial issue and worldwide. In many countries occred violence against women. In France recorded 95 percent of the victims are women, and 51 per cent of the proportion of the violence committed by the victim's husband. In Bangladish,murder of wife carrying 50 percent of the total number of homicides occurred throughout the country. In Pakistan 99 percent of housewives are victims of violence of her husband. In India approximately 25,000 dead bride were burnt every year because of the problem of dowry. In Japan 15 percent and 71 percent of women reported getting violence by the husband. Meanwhile, in more than 80 countries worldwide, 35 percent of women get physical or sexual abuse by the husband. ${ }^{1}$

In the United States the violence against women often occurred. Dickinson and Lemming said, between 50-75 percent of the women had been beaten by their partners. Husbands burned their wives, later reported as an accident or committed suicide so that the husband can marry again. Murder 'respectable'or honor killing occurred in Middle Eastern countries such as Jordan, Pakistan, Syria, Iraq and in several countries in the Persian Gulf, raped women were killed by their own families to preserve family honor.

Based on the report of the UN Declaration on the Elimination of Vio- lence Against Women, it wasstated that violence was a manifestation of unequal power relations between men and women, resulting in suppression or discrimination against women. UN statis- tics showed that domestic violence resulted in losses of approximately USD 1:16 billion per year in Canada, US \$ 5.8 billion per year in the United States and USD 11:38 billion per year in Australia and this did not include the cost of health services provided for the violence. $^{2}$

In Indonesia, violence against wom- en tends to increase in each year as reported by the Indonesian National Commission for Women. The report is not representative of the overall amount of the actual cases in the

\footnotetext{
Violence against Women, Intimate Partner and SexualViolence against Women, http://www.who.int/mediacentre/factsheets/fs239/ en/(retrieved: Aug 26,2016).

http://insightsabah.gov.my/article/read/2537 (retrieved: Aug 26,2016).
} 
community (tips of iceberg). According to the National Commission for Indonesian Women, there wasan increase of domestic violence each year. In the year of 2011, it was recorded 124555 cases, 216156 in 2012, 279760 in 2013, 293220 in 2014, and 321752 in 2015.

According to the reports, many victims of violence did not report cases to authorities for various reasons such as embarrassment to receive disgrace, to avoid negative views on society,no understanding on law, as well as the lengthy trial process, misleading and exhausting. Therefore an effort to handle this case, the government faced various impediments including strong patriarchi culture, law enforcement which did not favor the victim, lack of information on abusement and service centers, and difficult to access by the victim, as well as the enactment of the system wasless sensitive to the developments in society.

Meanwhile, Women's Crisis Centrerecorded 8 of 10 women who came to Mitra Perempuan experienced in violence by her husband and her ex-husband as: i) Nine of 10 women experienced more than onetype of violence (physical, psycholo- gical, sexual or neglect/econo-mics), on the side facing marital discord; ii) Nine of 10 women received the consequences of violence on mental health including an attempt ofsuicide, has implications for physical and reproductive health; iii) Nine of 10 women experienced in violence and sexual disorders during courtship by a male friend or partner; iv) Three of 10 women ever got health care or legal assistance; v) Two of 10 women used counceling; vi) Two of 10 women chose law action; vii) six of 10 women were referral from the National Commis- sion for
Women, the police and hospitals; viii) Two of 10 women received information from the Women Crisis Centre (WCC); and ix) three of 10 women received information from the media. $^{3}$

Various forms of violence, especially domestic violence is considered as a violation of the principles of human rights, crimes against human dignity, and as a form of discrimination. In addition, the developments in this period shows that the violence is real so that we need an act for the prevention of such crimes. To avoid the many victims of domestic violence, many countries in the world made efforts, as done by the Agency for International Human Rights. In the trial of the International on Population and Development in Cairo in 1994 provided important notes about the efforts to eliminate discrimination, sexual harass- ment and violence against women, and was hoped to followwith special legislation. Some acts were enacted in the worldamong them: in New Zealand, The Domestic Vilolence Act 1995; in Taiwan, Prevention and Treatment of Domestic Vilolence Act 1998; in Japan, the Law for the Prevention of Spousal Violence and the Prevention of Victims 2001, in Malaysia, Domestic ViolenceAct 1994; and in Indonesia, Domestic Violence Act 2004. ${ }^{4}$

\footnotetext{
MitraPerempuan'Women's Crisis Centre, 3 Januari,

2012,http://perempuan.or.id/kategori/statistikcatatan-tahunan/tahunan/(retrieved: Aug 26, 2016).

4 Jal Zabdi Mohd Yusoff, Jenayah Keganasan Rumah Tangga, First Edition,Kuala Lumpur: Universiti Malaya, 2004,p 56.
} 


\section{ANALYSIS AND DICUSSION}

\section{The Meaning of Violence}

It is a common mistake and a very dangerous when many people argue that domestic violence isonly in physical form. This is because the brand just look at their signs of physical violence on the victim's body. Though the violence can also be in other forms namely non-physical or verbal, and frequently verbal abuse may increase to physical violence. ${ }^{5}$

The concept of "violence" has a different sense. It is very dependent on the standpoint of where to see. Sometimes a form of verbal violence in a country is not considered as violence, as well as physical violence or psycholo- gical specific scope in a culture is not also regarded as an act of violence. Therefore, "violence" essentially is a concept that the meanings and contents are very much dependent on norms and a growing understanding in a society itself. In addition ,the term "violence" is also used to describe the behavior ofboth the overt, covert, offensive or defensive which accompanied the use of force to others.

Domestic violence has various definations. The "violence" itself is defined as an act of a person or group of people which causes injury or the death of another person, or causesphysical damage or other people's stuff. These include all acts of violence based on the gender differences that result or may result in the misery or suffering; sexual, and psychological, including the threat of certain actions,

http://www.lgbt.uncla.edu/findout_violence.htnl. (retrieved: Aug 26, 2016). coercion or arbitrary deprivation of liberty. Both of which occur in the presence of lay people or in private life. The violence does not stand alone, but it deals with a wide range of conditions and developments in the political, economic and socio-cultural life ina community, becoming a social problem that needs sensitivity, concern and responsibility of all parties for handling. prevention and mitigation. ${ }^{6}$ According to the Oxford Dictionany of Law, Domestic violence has been defined as a battered spouse or cohabitation which means a person subjcted to the physical violence by their husband, wife, or cohabitant. ${ }^{7}$

Meanwhile in the context of violence against women, Lily Zakiyah Munir said in the broad definition of violence, that is "all acts against women or other subordinate groups that resulted or may result in losses or physical suffering, sexual, economic or psychological, including threats to commit such acts, coercion or eliminate the freedom unilaterally within the scope of the household ". 8 In the feminist dialectic, violence is understood as a form of male power (which is natural, biological) against women. It is also said in the beginning that this concept only covers the personal aspects and tends to emphasize the forms of physical violence and men's sexuality. But the concept was then changed after debate among the feminists. Violence against

\footnotetext{
Tutty Alawiyah, Kekerasan Seksual Wanita Sebagai Isu GlobalDalam Kata dan Perbuatan,Jakarta:Kantor Menteri Negara Peranan Wanita RI, 1999,p106.

7 Elizabeth A. Martin (ed), Oxford Dictionary of Law, New York: Oxford University Press, 1997.

8 Lily ZakiyahMunir, Stop Kekerasanterhadap Perempuan, www.kompas.com/kompas(retrieved: Aug 26, 2016).
} 
women was then understood as a manifestation of patriarchy that was, a system in the community who put themas the party in power, which were entitled to dominate and control women as subordinant party.Then the development of this concept had been published in the Declaration of the UN in Beijing 1994 which defined violence against women as any act based on gender differences which result in women suffering physically, sexually, or psychologically including threats of arbitrary action. Both are valid in public as well as in personal life.

\section{Violence in Domestic Violence Act 23, 2004}

Nowadays, as Musdah Mulia $^{9}$ saidthe problem of domestic violence is very interesting in the discussion when the problem itself is viewed from the perspective of law. This is because of the belief towards the positive law that does not really provide adequate protection for the victim. Very often the law is only used to justify a form of violence, whereas the effect of violence is very serious, causing physical and mental hurt, as well as suffering and misery.

The rise of violence around the world has led to the rise of the world community to oppose violence as a whole, has taken a more proactive approach in dealing with the problem. Many countries haverecognized that violence is an act that violates human rights. ${ }^{10}$ Violence has very heavy

\footnotetext{
9 Musdah Mulia, 2002, "Kekerasan terhadap Perempuan (Mencari Akar Kekerasan dalam Teologi),"Journal Women in Islam, Vol. I, p 66.

10 Jal Zabdi Mohd Yusoff.Note 4.pp. 22-23.
}

impact. ${ }^{11}$ Therefore, many countries in the worldhas created and enacted actsrelating to domestic violence. In addition, the increasing cases of violence both in public or domestic sphere and noform of protection for victims of violence, has existed kind of thinking to make a provision of law that can punish the perpetrators.

In 1967, the United Nations (UN) has issued a declaration on the Elimination of Discrimination against Women. The declaration contains rights and obliga- tions of women based on the equality and rights to men and told them to take the necessary steps to ensure the imple- mentation of the declaration. The re-sulting declaration is not binding, it is based on the declaration of the UN Commission on the Status of Women relating for preparing Draft Convention on the woman. Then on December 18, 1979, the UN General Assembly adopted the Convention on the Elimination of All Forms of Discrimination against Women(CEDAW). ${ }^{12}$

Based on the convention, countries committed to undertake a series of measures to end discrimination against women in all its forms: to integrate the principle of equality of men and women in their legal

11 Malaysian Ministry of Health: Domestic Violence (2008)

http://www.infosihat.gov.my/penyakit/Dewasa/Ke ganasanRumahtangga (retrieved: Sept 11, 2016).

12 UN Convention on the Elimination of All Forms of Violence Against Women (CEDAW) is theConvention on the Elimination of All Forms of Discrimination against Women, adopted in 1979 by the UN General Assembly. Convention is often described as an international demands for women's rights, consisting of a preamble and 30 articles. The Convention also defines a so-called discrimination against women and sets up an agenda for national action to end such discrimination. 
system, abolish all discriminatory laws and adopt the principles which prohibit discrimination against women; providejustice and other public institutions to ensure the effective protection of all discrimination against women; and ensure elimination of all acts of discrimination against women by persons, organizations or enterprises. The Convention also provides the basis for realizing equality between women and men by ensuring equal access to women in political and public life, including the right to vote and to stand, education, health and employment. The countries agreed to take appropriate steps, including legislation and temporary special measures, so that women can enjoy all human rights and fundamental freedoms. In addition, countriesthat have ratified or acceded to the Convention are legally bound to put its provisions into practice. Countries also committed to submit national reports, at least every four years, on steps they have taken to comply with their treaty obligations.

Violence is defined as an act of anyone against someone, especially women, which gives effects to misery or physical, sexual,psychological suffering, and/or negligence of household, including threatment to do coercion, or deprivation of liberty against the law in the domestic sphere ${ }^{13}$ Meanwhile the domestic vio- lence in accordance to the Domestic Violence Act 23, 2004 is devided into physical violence, psychological vio- lence, sexual violence; or neglect of household. ${ }^{14}$ Physical abuse is defined as acts that result in pain, illness; or serious injury, whereas psychological

\footnotetext{
13 The 2004 Law No. 23 on Indonesian Domestic Violence, Section 1 (1).

14 Section 5. Note 13.
}

violence is an act that results in fear, loss of self confidence, loss of ability to act, a sense of helplessness, and/or serious psychic suffering on someone. ${ }^{15}$

It is also explained that the family or household in this law includes; husband. wives and children; people who have a family relationship with her husband. The wives and children are because of blood relations, marriage, dairy, parenting, and guardianship who settle in the household; and/or people working to assist the household and living in the household. Furthermore, according to the Law No. $23^{16}$ mentions that people working to assist the household and living in the house is alsoregarded as a family member within a period to be in the household.

Moreover other violence such as sexual violence is defined as forcing sexual intercourse carried out against an individual living within the scope of the household, and forcing sexual intercourse against individuals within the scope of the household for commercial purpose or specific purpose. While ignorance of households is defined as any act that resulted in the victim's economic dependence by limiting or prohibiting eligible to work inside or outside the home so that the victim is under the control of the person. ${ }^{17}$

Domestic violence theoretically can be in the form of physical persecution such as being hit, kicked, slapped and so forth.In addition to domestic violence it can also be in the form of psychological abuse or emotional abuse such as: threat, jibe, finacial

\footnotetext{
5 Section 7. Note 13.

6 Section 2. Note 13.

17 Section 9. Note 13.
} 
flogging or basic necessities and sexual abuse. According to M.M. Billah (1999) those forms of domestic violence are not only limited to physical, but also in the three forms of other violence, they aresexual assault, economic violence, psychological and emotional violence. ${ }^{18}$ Siti Ummu Adillah (2008) stated, domestic violence is essentially all forms of behavior conducted by a person or group against another person or group of people causing negative effects physically, emotionally and psychologically for the victims. ${ }^{19}$

\section{Legal Protection of the Domestic Violence Act 23, 2004}

Domestic violence is an outstanding crime against humanity. Therefore the Indonesian Government againsts this crime by the reasion that it is not in accordance with the Indonesian Constitution $1945 .{ }^{20}$ Meanwhile, the Indonesian government considers that violence against women is a form of discrimination against women, and to eleminate this, the goverment issued the discrimination Act 7, $1984 .^{21}$ To run this, the government through Presidential Decree established the Commission on Violence

18 Look M.M. Billah in Syafiq Hasyim, Menakar "Harga" Perempuan, Bandung: Mizan,1999,p263.

19 Siti Ummu Adillah, 2008, "Analisis Penanganan Isteri Sebagai Korban Kekerasan Dalam Rumah Tangga (KDRT) Akibat Perlakauan Suami (Studi Kasus di Kawasan Tambak Lorok Semarang),"Jurnal Hukum "Khaira Ummah",Vol. III, No. 1, p111.

20 The Indonesian Constitution 1945, Section 28 B (2).

21 The 1984 Law No. 7 on the Ratification the Convention of the Elimination of All forms of Discrimination against Women. against Women. ${ }^{22}$ Then in 2004, the Indonesian government issued an Act that specifically regulates domestic violence, Domestic Violence Act 23, 2004.

The Domestic Violence Act 23, 2004 was established to protect family members from various forms of violence. The purpose of protection was then poured in the form of draft legislation against domestic violence. It was based on the notion that domestic violence is a form of attack on honor, independence and safety of the victim soul. Thus placing it in the form of legislation was considered in line with the concept of the act matter itself, namely that this actis regardedas a demand for the legal protection of human rights in the household sector.

Article 1 (2) states that the elimination of domestic violence is a guarantee of the government to prevent the occurrence of domestic violence, to take action against perpetrators of domestic violence, and to protect victims of domestic violence. ${ }^{23}$ According to Neni Utami Adiningsih (2004), the existence of this act provides a flicker of hope for wives to protect themselves. In addition, when this legisla-tion is implemented consistently, then the legislation will help to safeguard women, especially for the wives of various violence for several reasons namely: first, it would make her husband no longer act arbitrarily against her. Violence by a husband is not a private affair, but it has been a public affairs; second, the penalties are high enough; third, today with only the testimony of victims plus one valid evidence

22 The Presidential Decree No. 7 of 1984 on the Commission of Violence against Women.

23 The 2004 Law No. 23 on the Indonesian Domestic Violence, Section 1 (2). 
(witness testimony, expert testimony, clue, letters and defendant testimony) can be the reason to prove the accused perpetrators of domestic violence. In addition, it has also agreed an additional criminal sanctions or alternative sanctions such as restrictions on movement of the perpetrator from the victim and the determination of the offender to comply with the counseling program under the supervision of specific institutions.

In order to prevent and protect victims, also to punish the perpetrators of domestic violence, the government and society shall carry out prevention, protection, and repression of the perpetrators, in accordance with Pancasila, the Indonesian's philosophy and theConstitution of 1945 . The various forms of violence. especially domestic violence is considered as a violation of human rights, a crime against human dignity, and any form of discrimination. Developments indicate that physical violance, emotional, sexual, and ignorance of household have become realistic so that we need acts and may provide benefit in prevention of such a crime. By it, Indonesian government has imposed a criminal act that is, the Act on the Elimination of Domestic Violence in 2004.

Domestic Violence Act 23, 2004 has four principles, they are: respect for human rights, justice, nondiscrimination, and protection of victims. In addition, this legislation is a guarantee of the govern-ment of Indonesia to the people with the purposes: to prevent all forms of domestic violence, to protect victims of domestic violence, to take action against perpetrators of domestic violence and to maintain the integrity of households harmonious and prosperous. ${ }^{24}$ In addition to regulate matters of prevention and protection and restoration of the victim, this act also regulates the particulars of the violence that occurred in households, different from criminal elements as stipulated in the criminal laws. Moreover, this act regulates matters of liability for the law enforcement, health personnel. social worker,volunteer, or spiritual director to protect the victims of such workers to be more sensitive and responsive to the interests of the household, which was originally directed to the integrity and harmony of a household.

In fact the responsibility of preven- tion of domestic violence is the responsi- bility of government and society. The government as a responsible party in efforts to prevent domestic violence according to article 12 (1) must:

1. formulate policies on the elimination of domestic violence;

2. provide communication, information, and education about domestic violence;

3. organize dissemination and advocacy on domestic violence; and

4. conduct gender-sensitive education and training and the issue of domestic violence,to set the standards and accreditation gender sensitive service.

People are asked to have responsibility in the prevention of domestic violence. Everyone who hears. sees or knows the occurrence of domestic violence shall make efforts in accordance with the limits of the

24 Section 3 and 4 . Note 23. 
ability under section 15 . They should strive to:

1. prevent the continuation of crime;

2. provide protenction to the victims;

3. provide emergency relief; and

4. assist the determination of the application process protection.

The Domestic Violence Act 23, 2004 was established to protect thevictims. Under the Domestic Violence Act 23, victims of violence have the rights to:

1. get protection rather than the family, police, prosecutor, court, lawyer, social institutions, or any partiesand based on the determination of a court order of protection;

2. get health care according to medical purposes; special handling related to the confidentiality of the victim;

3. get assistance by social workers and the help of lawyers at every level of the process according to the legislative provisions and inspection;

4. get spiritual guidance services.

Furthermore, Article 10 states that victims are entitled to:

1. Protection of the family, police, attorney, court, advocates, social institutions, or other parties either temporarily or by determination of protection from the courts;

2. Health services in accordance with medical needs;

3. Special handling related to the confidentiality of the victim;

4. Accompaniment by social workers and legal assistance at every level of examination process in accordance with the provisions of the legislation; and

5. Service of spiritual guidance.

\section{CONCLUSION}

The Domestic Violence Act 23, 2004 was established to protect family members from various forms of violence. This Act has divided domestic violence into four types namely physical violence,psychological , sexual, and neglect of household,as well as providing certain rights to victims.As a crime, violence in various types and forms presumably will never be lost on this earth as with other crimes. However it does not mean we feel pasimistic to attempt deletion of the crime. This problems be solved legally by implementing the act of domestic violence effectively, and non juridically to change attitudes and behavior patterns of the community involving many parties. The community nowadays has realized that such violence and abuse must not be condoned and addressed through legislation, consistent control by the person in authority as well as the criminal justice sytem.

\section{REFERENCES}

Adillah, Siti Ummu., 2008. "Analisis Penanganan Isteri Sebagai Korban Kekerasan Dalam Rumah Tangga (KDRT) Akibat Perlakauan Suami (Studi Kasus di Kawasan Tambak Lorok Semarang),"Jurnal Hukum "Khaira Ummah”, Vol. III, No. 1.

Alawiyah, Tutty. 1999. "Kekerasan Seksual Wanita Sebagai Isu Global," Jurnal Kata dan Perbuatan, Jakarta: Kantor Menteri Negara Peranan Wanita RI.

Hasyim, Syafiq. 1999. Menakar "Harga" Perempuan. Bandung: Mizan. 
http://insightsabah.gov.my/article/read/2537. (retrieved: Aug 26, 2016).

http://www.lgbt.uncla.edu/findout_violence. htnl. (retrieved: Aug 26, 2016).

Lily Zakiyah Munir, Stop Kekerasan Terhadap Perempuan, www.kompas.com/kompas. (retrieved: Aug 26, 2016).

Informasi penting tentang kekerasan terhadap perempuan dan anak. http://www.jurnalperempuan.com.retrieved: Aug 26, 2016).

Malaysian Ministry of Health: Domestic Violence (2008)

http://www.infosihat.gov.my/penyakit/Dewa sa/KeganasanRumahtangga. (retrieved: Sept11, 2016).

Martin, Elizabeth A. 1997.Oxford Dictionary of Law. New York: Oxford University Press.

Mitra Perempuan, Women's Crisis Centre, January 3, 2012, http://perempuan.or.id/kategori/statistikcatatan-tahunan/tahunan/. (retrieved: Aug 26, 2016).

Mulia, Musdah. 2002.“Kekerasan Terhadap Perempuan (Mencari Akar Kekerasan dalam Teologi),"Journal Women in Islam, Vol I.
The Indonesian Constitution 1945.

The Presidential Decree No. 7, 1984 on the Commission of Violence against Women.

The UN Convention on the Elimination of All Forms of Discrimination against Women (CEDAW).

The 2004 Law No. 23 on Domestic Violence.

The 1984 Law No. 7 on Ratification of the Convention on the Eliminition of All Forms of Discrimination against Wemen.

Violence against women, Intimate partner and sexual violence against women, http://www.who.int/mediacentre/fact sheets/fs239/en/. (retrieved: Aug 26, 2016).

Yusoff, Jal Zabdi Mohd. 2004. Jenayah Keganasan Rumah Tangga, Kuala Lumpur: Universiti Malaya. 